\title{
Development and validation of a diagrammatic scale for quantifying maize leaf spots caused by Diplodia macrospora
}

\section{Desenvolvimento e validação de escala diagramática para quantificação da mancha foliar de Diplodia macrospora em milho}

\author{
Eloisa Lorenzetti ${ }^{1 *}$; Juliano Tartaro ${ }^{2}$; Alfredo José Alves Neto ${ }^{1}$; Anderson Luis \\ Heling ${ }^{1}$; Jeferson Carlos Carvalho; ${ }^{1}$ José Renato Stangarlin ${ }^{3}$; Odair José Kuhn³; \\ Roberto Luis Portz ${ }^{4}$
}

\section{Highlights:}

Novel diagrammatic scale for quantifying maize leaf spots caused by Diplodia macrospora. This scale improves accuracy and precision in disease assessment. Useful tool to facilitate assessment of disease severity.

\begin{abstract}
The objective of this study was to develop and validate a diagrammatic scale to evaluate the severity of spots on maize leaves caused by the fungus Diplodia macrospora. Severity ranged between the minimal $(0.5 \%)$ and maximal $(55 \%)$ limits of disease severity, and intermediate severity levels were defined according to the "Weber-Fechner stimulus response law". The proposed scale describes six levels of severity based on how much of the leaf is affected: $0.5 \%, 3 \%, 8 \%, 23 \%, 36 \%$, and $55 \%$. Validation was carried out by eight evaluators, four inexperienced and four experienced. They estimated the severity of disease in 60 maize leaves, with and without the proposed diagrammatic scale. A relationship was shown by regression analysis between estimated and actual severity, with and without the use of the scale. When both inexperienced and experienced evaluators used the scale, they were able to estimate disease severity more accurately and precisely.
\end{abstract}

Key words: Disease assessment. Epidemiology. Pathometry. Zea mays L.

\section{Resumo}

O objetivo deste estudo foi desenvolver e validar uma escala diagramática para avaliação da severidade da mancha foliar causada pelo fungo Diplodia macrospora, em folhas de milho, considerando os limites de severidade mínima e máxima da doença e os níveis intermediários de acordo com a "Lei de resposta ao estímulo de Weber-Fechner". A escala proposta apresenta seis níveis de severidade: $0,5 \% ; 3 \% ; 8 \% ; 23 \% ; 36 \%$ e $55 \%$ da área foliar afetada. A validação foi realizada por oito avaliadores sendo quatro inexperientes e quatro experientes, os quais estimaram a severidade de 60 folhas de milho

\footnotetext{
Discentes, Pós-Graduação em Agronomia, Universidade Estadual do Oeste do Paraná, UNIOESTE, Marechal Cândido Rondon, PR, Brasil. E-mail: eloisa-lorenzetti@hotmail.com; alfredo.alves.neto@hotmail.com; andersonheling@gmail.com; jefersoncarvalho@outlook.pt

2 Eng ${ }^{\circ}$ Agr $^{\circ}$, UNIOESTE, Marechal Cândido Rondon, PR, Brasil. E-mail: julianotartaro@hotmail.com

3 Profs., UNIOESTE, Marechal Cândido Rondon, PR, Brasil. E-mail: jose.stangarlin@unioeste.br; ojkuhn@gmail.com

4 Prof., Universidade Federal do Paraná, UFPR, Palotina, PR, Brasil. E-mail: portz_r@hotmail.com

* Author for correspondence
} 
que apresentavam níveis variados se sintomas da doença, primeiramente sem a utilização da escala diagramática e, posteriormente, com o uso da escala proposta. Pela análise de regressão verificou-se relação entre o grau de severidade real e o estimado por cada avaliador, com e sem o uso da escala. Com a utilização da escala, tanto os avaliadores inexperientes quanto os experientes demostraram maiores níveis de acurácia e precisão.

Palavras-chave: Avaliação de doença. Epidemiologia. Fitopatometria. Zea mays L.

\section{Introduction}

Maize (Zea mays L.) is a prominent type of cereal grain with important economic and social contributions (CONAB, 2019). According to the Food and Agriculture Organization (FAO, 2017) in 2017, Brazil has become the world's second largest exporter of maize, producing over 95 million tonnes in the 2018/2019 harvesting season, producing an average of $5,524 \mathrm{~kg} \mathrm{ha}^{-1}$ (CONAB, 2019).

Previous studies report that maize yield can reach 19,113 $\mathrm{kg} \mathrm{ha}^{-1}$ (OLIVEIRA et al., 2013) indicating that the current productivity is low. Therefore, factors that affect crop productivity should be studied.

Plant diseases are among the various factors that may contribute to reducing crop yields (BERGAMIN FILHO; AMORIM, 2018).

Maize crops are constantly kept in growth cycles. After irrigation, they grow in the summer season, and after the cultivated area increases, they grow again in the autumn season. This process increases the possibility of new diseases emerging (CARVALHO; PEREIRA; CAMARGO, 2016). Residue from the maize crops remain in the soil due to the absence of crop rotation. This favors survival of various phytopathogens and rapid development of diseases (BERGAMIN FILHO; AMORIM, 2018).

Among the types of diseases that occur in maize crops, there is a type of leaf spot caused by the fungus Diplodia macrospora Earle Sutton [Sin. Stenocarpella macrospora (Earle)], which has become increasingly problematic in recent years (CARVALHO; PEREIRA; CAMARGO, 2016).
D. Macrospora lesions are necrotic that are striated and elliptical. They present with chlorotic margins and a necrotic center. It is possible to observe the initial point of infection, where the black and globous pycnidia forms and contains the conidia (CARVALHO; PEREIRA; CAMARGO, 2016), These lesions cause a decrease in the photosynthetic area. This same pathogen can cause stem rot, spike rot, and pounded grains (SIQUEIRA et al., 2014), decreasing productivity and quality of the grain (BAMPI et al., 2012).

The ideal conditions for conidia germination are $>50 \%$ relative humidity (LATTERELL; ROSSI, 1983), and temperatures ranging between $25{ }^{\circ} \mathrm{C}$ to $32{ }^{\circ} \mathrm{C}$ (EDDINS, 1930). This process was initiated between 12 to $15 \mathrm{~h}$ after its deposition in the host plant at $28^{\circ} \mathrm{C}$ (BRUNELLI et al., 2005).

To understand disease etiology and symptoms, it is important to be able to determine the severity, thus requiring the use of diagrammatic scales for quantification (ALVES et al., 2015).

No diagrammatic scales are available to assess the severity of $D$. macrospora-induced leaf spots. Severity is assessed by estimating the area of the leaf that is infected. This scale is easy to use and can reduce errors in assessments by improving accuracy and precision by providing images to show the symptoms of the disease at various levels of severity (AMORIM; BERGAMIN FILHO, 2018).

In establishing the diagrammatic scale, we had to consider the minimum and maximum severities of disease observed in the field, intermediate levels of disease that comply with the law of stimulus response (Weber-Fechner), and whether these 
levels reflected that observed in our leaf samples (AMORIM; BERGAMIN FILHO, 2018).

The aim of this study was to develop and validate a diagrammatic scale to quantify spotting severity caused by $D$. macrospora in maize leaves.

\section{Material and Methods}

A diagrammatic scale for evaluating $D$. macrospora-induced maize leaf spots was generated from 60 leaves collected in January 2017 from a commercial farm in Toledo, in the western region of the Paraná state. These leaves were heterogeneous for disease severity, and were collected at phenological stage R4 (farinaceous grain). The middle section of the leaf (about a third of the area) was photographed with a digital camera and analyzed in Quant-v1.0.0.22 (VALE; FERNANDES FILHO; LIBERATO, 2001). The severity of the disease was determined based on the percentage of injured surface leaf area relative to the total leaf area.

To define the parameters of the scale, the minimum limit (least amount of disease observed), and the maximum limit (amount of disease in which senescence occurs) were determined. The intermediate severity levels were selected according to Weber-Fechner's Law of visual acuity. Additionally, we considered the shape, distribution, and frequency of the lesions. A diagrammatic scale with six increasing severity levels $(0.5 \%, 3 \%, 8 \%$, $23 \%, 36 \%$, and $55 \%$ ) based on the affected leaf area was proposed (Figure 1). The necrotic part of the leaf and the yellowish halo present in the lesions were considered as a diseased area.

To validate of the scale, 60 digital photographs of the maize leaves with varying disease severity were randomly arranged. The photographs were evaluated by eight evaluators. Evaluators 1-4 had no prior experience with disease assessment. Evaluators 5-8 had prior experience with evaluating disease with some type of diagrammatic scale. The assessments were performed twice by each evaluator; first without the scale, and then using the proposed diagrammatic scale.

The accuracy and precision of the assessments done by the evaluators were determined by linear regression analysis. The slope of the regression line was kept constant, where the actual and estimated severities were regarded as the independent and dependent variables, respectively. We show that it was possible to determine the relationship between actual and estimated severity, with and without the use of the scale.

The accuracy of the estimated assessments were determined by the $\mathrm{T}$ test (95\% confidence interval) with the slope of the equation of the line (a) to verify if it was significantly different from 1 , and the linear coefficient/intercept (b) to test whether it was significantly different from 0 . The (b) values that are significantly different than 0 indicate constant deviations. The (a) values that are significantly different than 1 indicate systematic deviations (ALVES et al., 2015). Thus, (a) and (b) deviating from 1 and 0 , respectively, indicated constant and systematic deviations in the evaluations (LENZ et al., 2010).

The precision of the evaluations was estimated by the coefficient of determination/correlation $\left(\mathrm{R}^{2}\right)$ using the same linear regression and the variance of absolute errors. These were obtained by subtracting the actual severity from the estimated determined by each evaluator (NUTTER JUNIOR; SCHULTS, 1995). 
Figure 1. Diagrammatic scale for evaluation of leaf spot severity caused by Diplodia macrospora (Stenocarpella macrospora) in maize (Zea mays L.). Values in percentage of leaf area with symptoms.

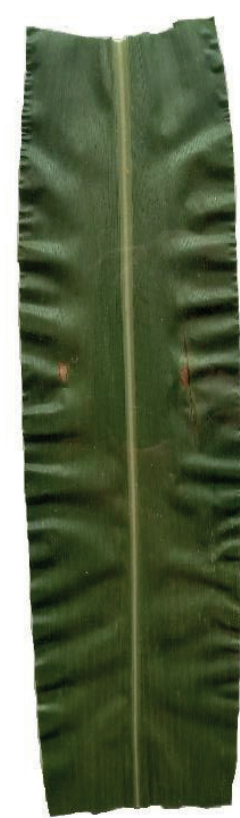

$0.5 \%$

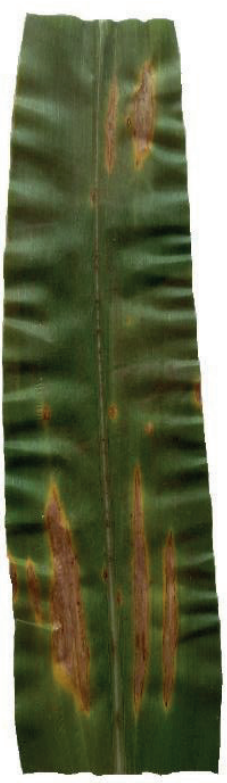

$23.0 \%$

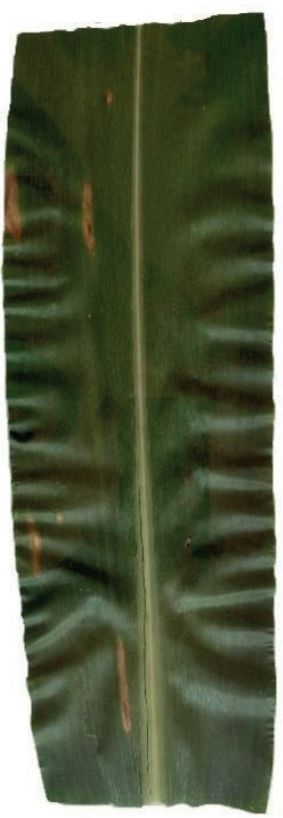

$3.0 \%$

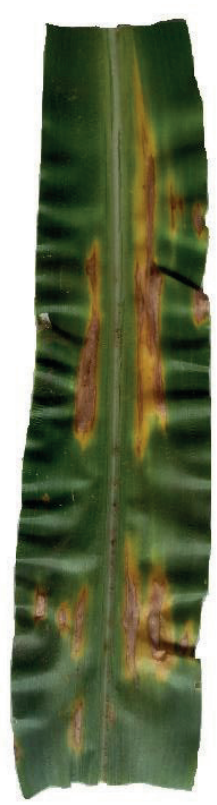

$36.0 \%$

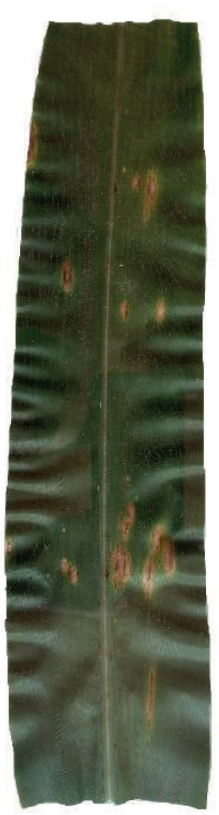

$8.0 \%$

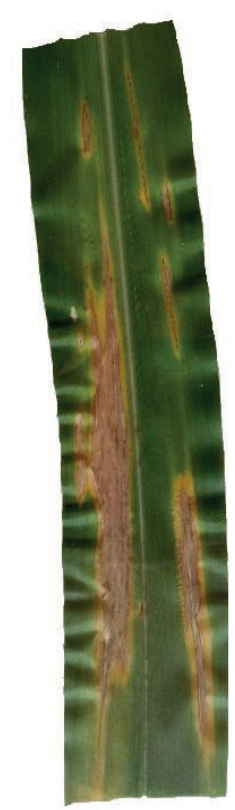

$55.0 \%$ 


\section{Results and Discussion}

The maximum and minimum limits of the diagrammatic scale proposed in this study were $0.5 \%$ and $55 \%$ affected leaf area, with four intermediate levels (Figure 1). This scale was prepared according to the Weber-Fechner law of visual acuity, considering yellow areas present around the areas already deteriorated by the pathogen.

The scale was validated to evaluate if it can be used to assess disease severity in field conditions by researchers and farmers.
Precision (repeatability) and accuracy (proximity of estimated value to the actual value) of the assessments were evaluated by linear regression analysis.

Accuracy refers to the degree of proximity between the estimated (b) and actual (a) values. The (b) and (a) values were closer to 0 and 1 , respectively, for experienced evaluators using the proposed diagrammatic scale (Table 1).

Table 1. Angular coefficient (a), linear coefficient (b), and coefficient of determination $\left(\mathrm{R}^{2}\right)$ of the linear regression between the real severity (independent variable) and the estimated severity (dependent variable) of leaf spot caused by Diplodia macrospora (Stenocarpella macrospora) in maize (Zea mays L.), by eight evaluators (1 to 4 inexperienced e 5 to 8 experienced) with and without the use of the proposed diagrammatic scale.

\begin{tabular}{|c|c|c|c|c|c|c|}
\hline \multirow{2}{*}{ Evaluator } & \multicolumn{3}{|c|}{ Without scale } & \multicolumn{3}{|c|}{ With scale } \\
\hline & $a$ & $b$ & $\mathrm{R}^{2}$ & $a$ & $b$ & $\mathrm{R}^{2}$ \\
\hline \multicolumn{7}{|l|}{ Inexperienced } \\
\hline 1 & $1.2165^{*}$ & 3.3036 & 0.6851 & 1.0615 & 2.1217 & 0.9090 \\
\hline 2 & $0.7583^{*}$ & 1.5919 & 0.6259 & 0.9221 & 0.8810 & 0.8985 \\
\hline 3 & 0.9251 & 1.7600 & 0.5499 & 0.9181 & 1.0423 & 0.8885 \\
\hline 4 & $0.6104^{*}$ & 0.8842 & 0.7492 & $0.3595^{*}$ & 1.1102 & 0.8943 \\
\hline \multicolumn{7}{|l|}{ Experienced } \\
\hline 5 & 0.8991 & 1.8305 & 0.7874 & 0.9450 & 1.0790 & 0.9379 \\
\hline 6 & $0.6014^{*}$ & 1.3084 & 0.5696 & 0.9357 & 0.4834 & 0.9290 \\
\hline 7 & $0.8650^{*}$ & 1.5486 & 0.7828 & 0.9371 & 0.9773 & 0.9088 \\
\hline 8 & $0.7262^{*}$ & $2.6881^{*}$ & 0.7721 & 0.9393 & 1.3700 & 0.9028 \\
\hline
\end{tabular}

*Situation in which the hypothesis of nullity $(\mathrm{a}=1$ or $\mathrm{b}=0)$ is rejected by the test $\mathrm{t}(\mathrm{P}<0.05)$. 
From the regression analysis data, we verified that the scale was effective in increasing accuracy and precision in the evaluation of disease (Table 1).

The (b) values from inexperienced evaluators without the scale, showed no indication of constant deviations, suggesting that the evaluators were able to perform an adequate evaluation with no statistical significance $(\mathrm{P} \leq 0.05)$ (Figure 2). Similarly, when these inexperienced evaluators used the scale, the evaluations were equally adequate, with no significance $(\mathrm{P} \leq 0.05)$ (Figure 3$)$.

The (a) values, from inexperienced evaluators 1 , 2 , and 4 , differed significantly from $1(\mathrm{P} \leq 0.05)$, indicating the presence of systematic deviations. These were improved with the scale by evaluators 1 and 2 , which were equal to $1(\mathrm{P} \leq 0.05)$. Without the scale, experienced evaluators 6,7 , and 8 had (a) values that were far from 1 . These errors were corrected when they used the proposed scale, as they all had values that were statistically equal to 1 .

When the scale was not used, experienced evaluators 5, 6, and 7 conducted assessments with (b) values equal to 0 , showing no deviation (Figure 2). Only the (b) value from the assessment by evaluator 8 was significantly different from 0 , showing significant errors. However, with the scale, this error was corrected and (b) value was statistically equal to 0 . The other evaluators continued to perform error-free assessments, as they maintained (b) values equal to 0 (Figure 3).

Therefore, use of the scale eliminated constant deviations and reduced systematic deviations in the assessments.
Precision, which refers to the repeatability or variation associated with an estimate, was estimated by the coefficient of determination $\left(\mathrm{R}^{2}\right)$ and variance of the absolute errors (NUTTER JUNIOR; SCHULTZ, 1995). Precision was higher with the use of the diagrammatic scale, both for inexperienced and experienced evaluators.

Precision of visual estimates of severity, without the use of the scale, performed by inexperienced evaluators was 0.6525 (Figure 2). This value was improved by $36 \%(0.8975)$ when the diagrammatic scale was used (Figure 3). Estimations performed by experienced evaluators without the scale, justified $0.7279 \%$ of the variation $\left(\mathrm{R}^{2}\right)$ (Figure 2 ). With the scale, experienced evaluators were more precise, with coefficients of determination averaging 0.9196 , improving by $26 \%$ (Figure 3 ).

Similar results were found in previous studies conducted by several researchers (ALVES et al., 2015; CAPUCHO et al., 2011; CUSTÓDIO ET AL., 2011; DOMICIANO et al., 2013; DUARTE et al., 2013; JULIATTI et al., 2013; LENZ et al., 2010; LIMA et al., 2013; NUNES; ALVES, 2012; REIS, CASA; BRESOLIN., 2013; SOUSA et al., 2014; TERAMOTO et al., 2011; TROJAN; PRIA, 2018), showing an increase in precision after using a diagrammatic scale, demonstrating the importance of this tool in quantifying disease severity.

Without the use of the diagrammatic scale, the average variation in absolute errors was -26.70 to 23.82 (Figure 4). With the use of the scale, the average variation was -13.00 to 14.10 (Figure 5). Average variation was decreased by approximately $46 \%$, demonstrating that overestimation, or underestimation, of severity can be decreased with the use of the proposed diagrammatic scale. 
Figure 2. Estimated severity without the use of the elaborate diagrammatic scale $(\bullet)$ and linear regression obtained between the real severity and the estimated (-), evaluating the leaf spot of Diplodia macrospora (Stenocarpella macrospora) in maize (Zea mays L.). The dotted line (•) represents the ideal situation, where estimated values are identical to the real. Evaluators 1 to 4 are inexperienced and evaluators 5 to 8 are experienced.

Evaluator 1

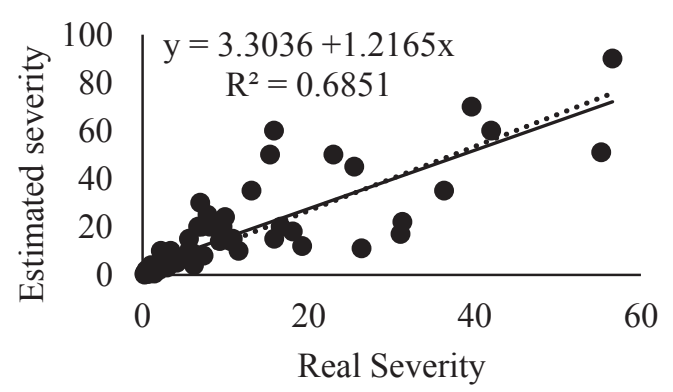

Evaluator 2

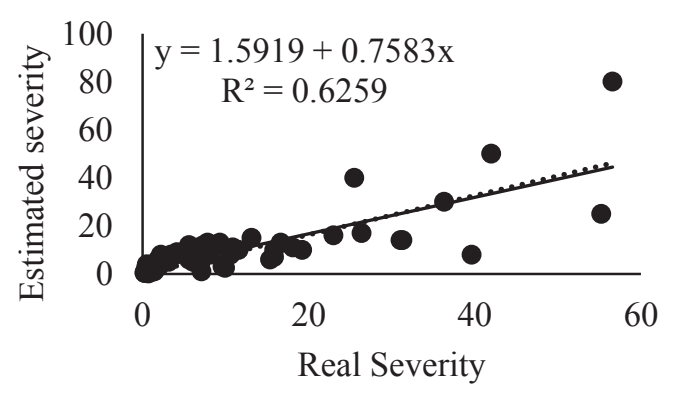

Evaluator 3

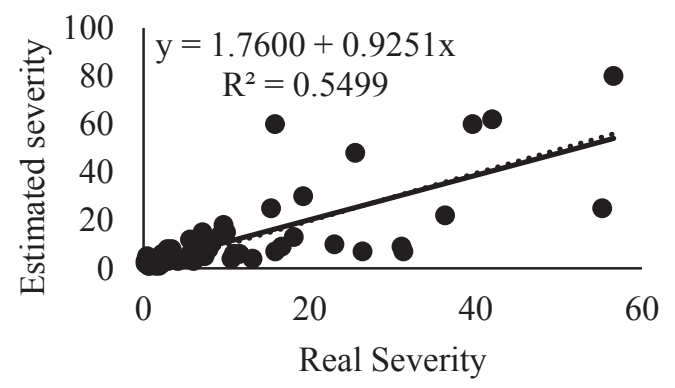

Evaluator 4

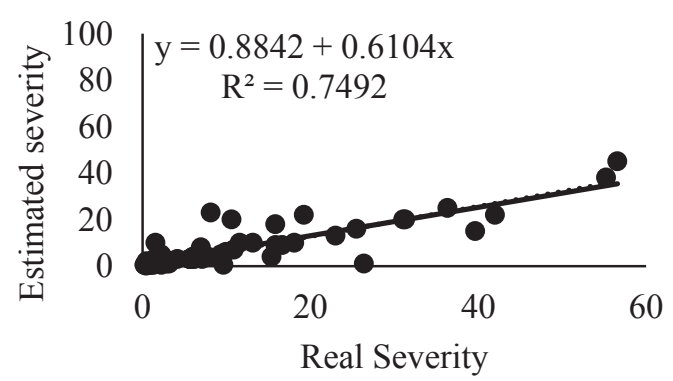

Evaluator 5

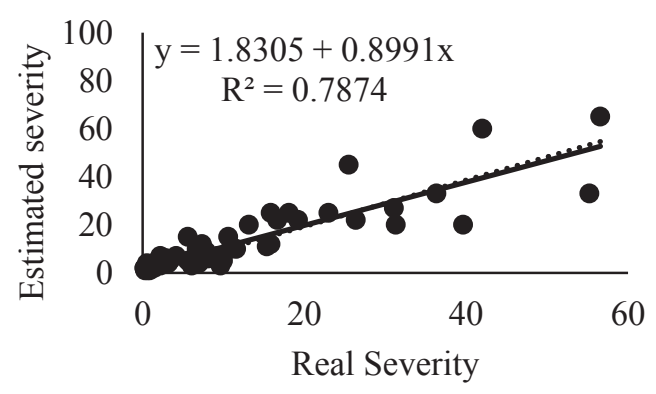

Evaluator 6

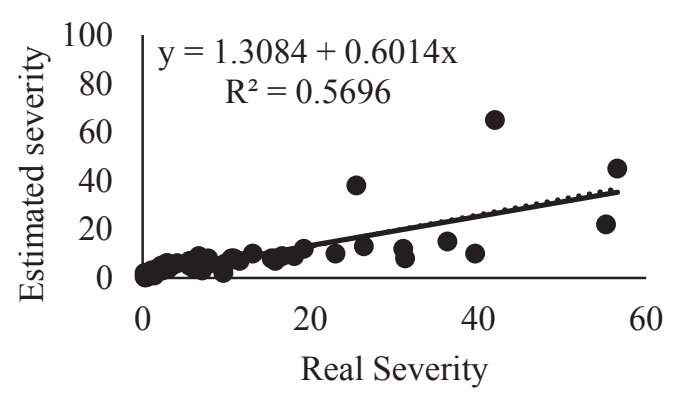

Evaluator 7

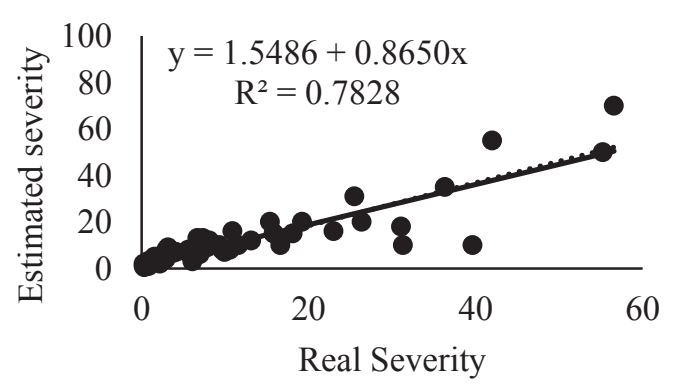

Evaluator 8

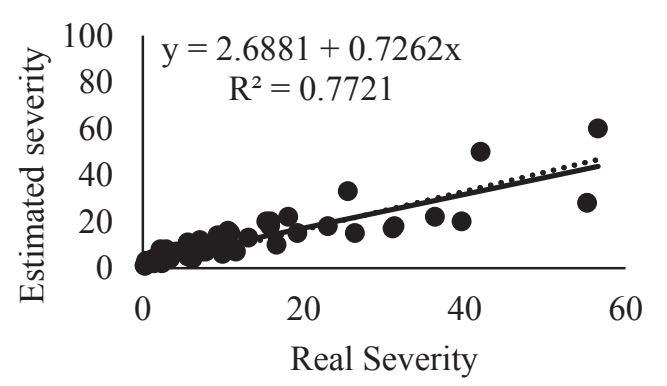


Figure 3. Estimated severity with the use of the elaborate diagrammatic scale $(\bullet)$ and linear regression obtained between the real severity and the estimated (-), evaluating the leaf spot of Diplodia macrospora (Stenocarpella macrospora) in maize (Zea mays L.). The dotted line (•*) represents the ideal situation, where estimated values are identical to the real. Evaluators 1 to 4 are inexperienced and evaluators 5 to 8 are experienced.

Evaluator 1

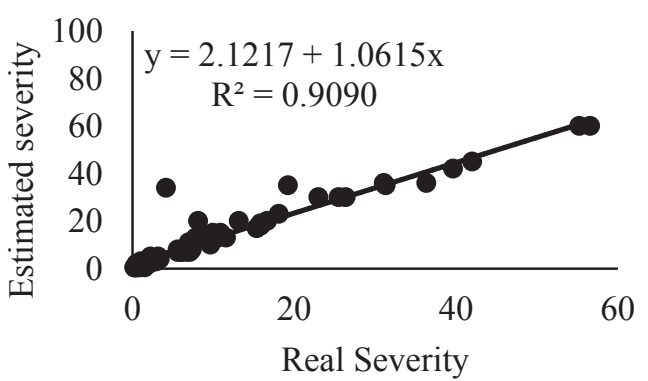

Evaluator 2

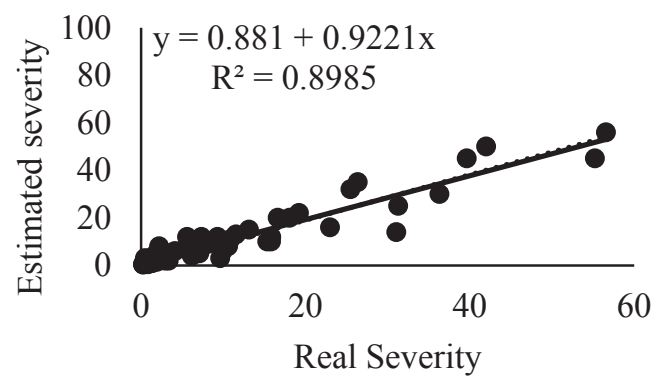

Evaluator 3

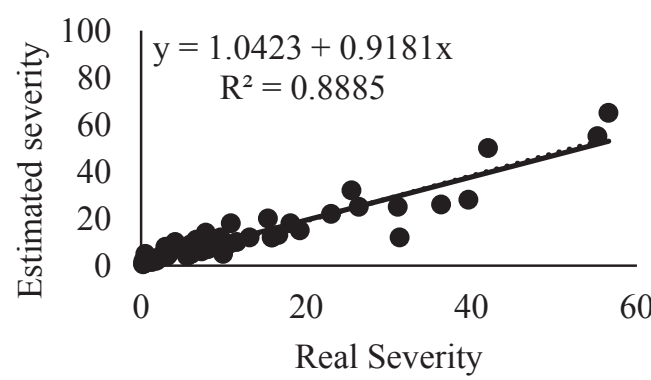

Evaluator 4

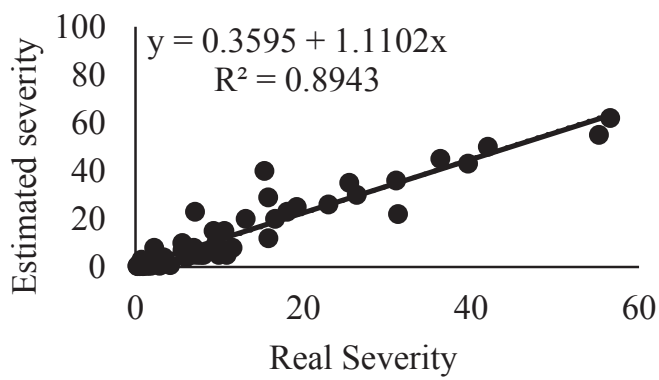

Evaluator 5

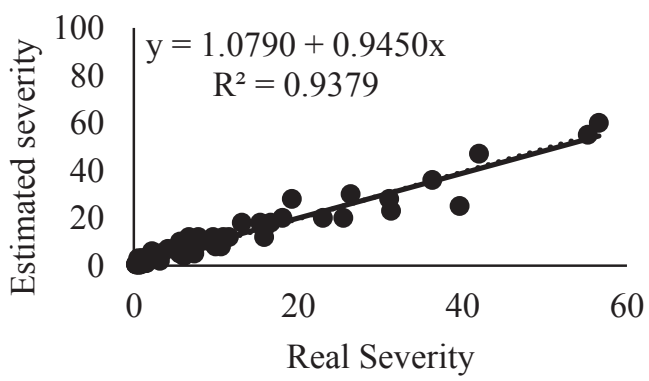

Evaluator 6

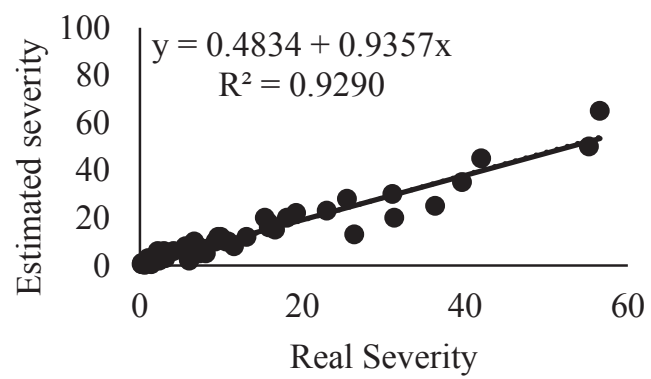

Evaluator 7

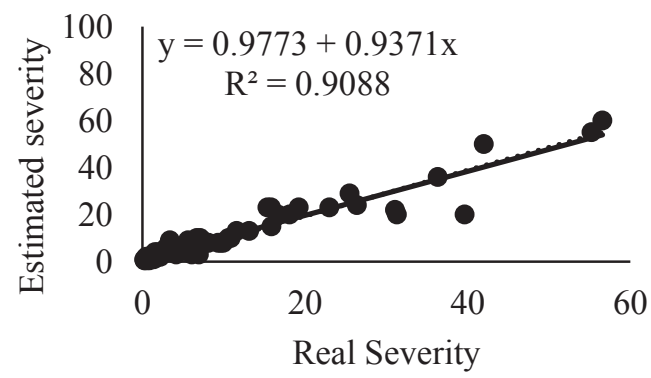

Evaluator 8

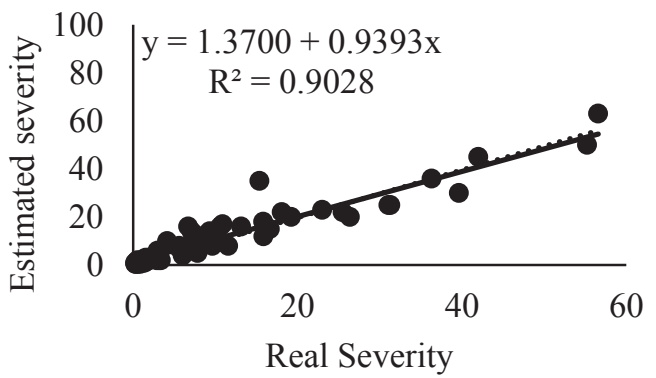


Figure 4. Absolute errors (estimated severity less real severity) for eight evaluators analyzing the leaf spot of Diplodia macrospora (Stenocarpella macrospora) in maize (Zea mays L.) without using the proposed diagrammatic scale. Evaluators 1 to 4 are inexperienced and evaluators 5 to 8 are experienced.

Evaluator 1

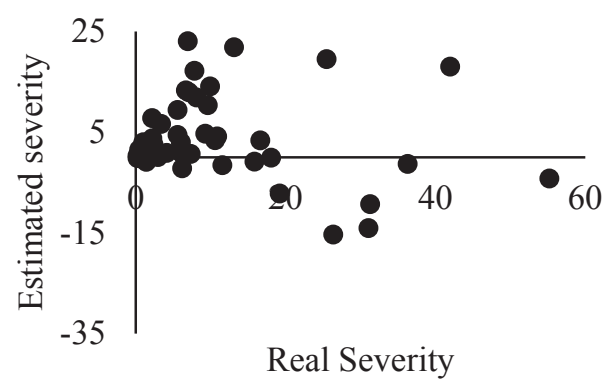

Evaluator 2

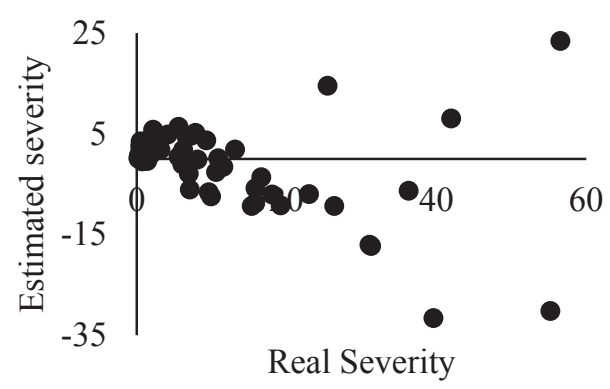

Evaluator 3

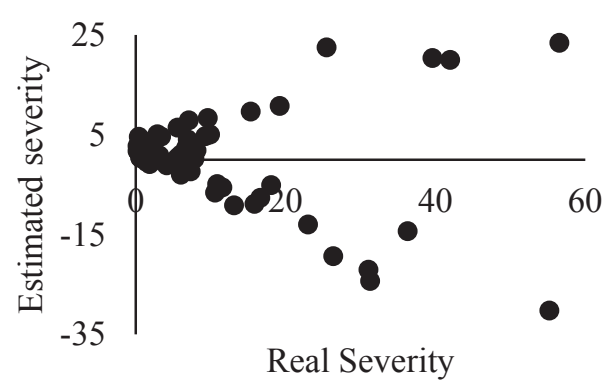

Evaluator 4

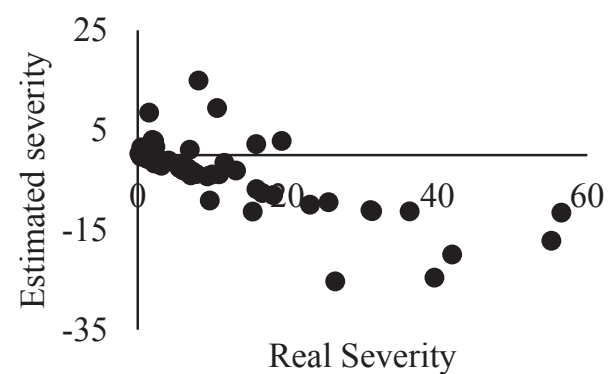

Evaluator 5

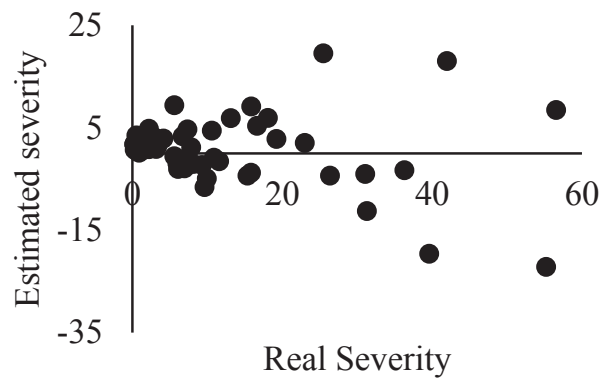

Evaluator 6

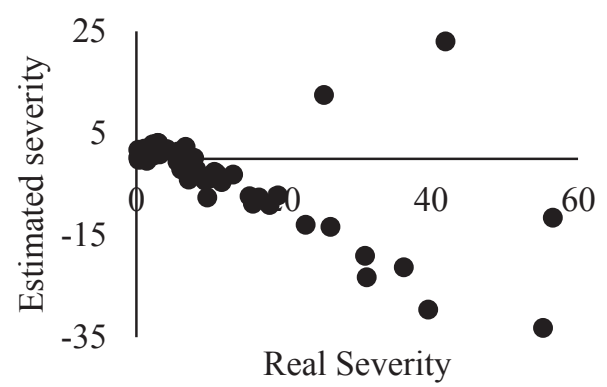

Evaluator 7

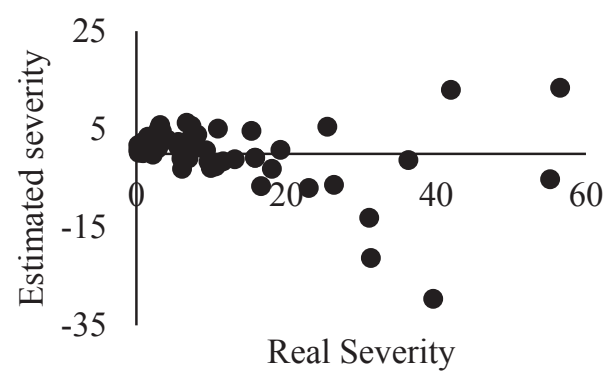

Evaluator 8

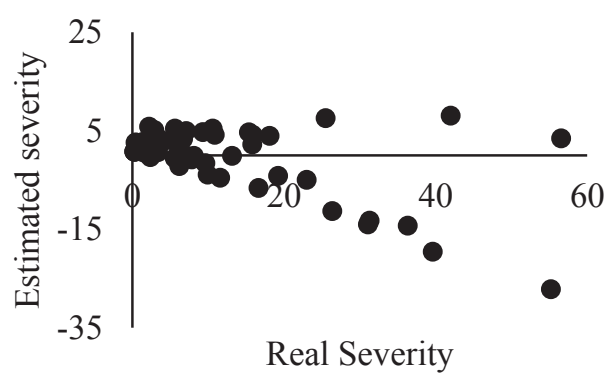


Figure 5. Absolute errors (estimated severity less real severity) for eight evaluators analyzing the leaf spot of Diplodia macrospora (Stenocarpella macrospora) in maize (Zea mays L.) using the proposed diagrammatic scale. Evaluators 1 to 4 are inexperienced and evaluators 5 to 8 are experienced.

Evaluator 1

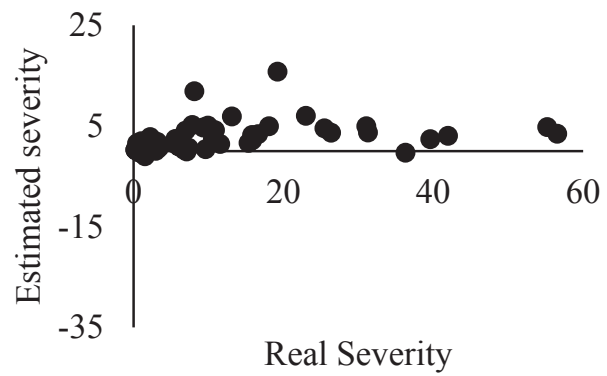

Evaluator 2

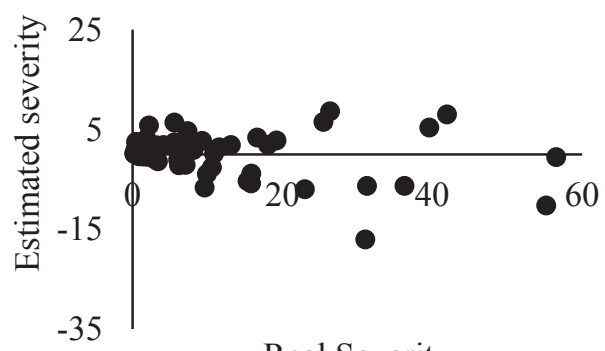

Real Severity

Evaluator 3

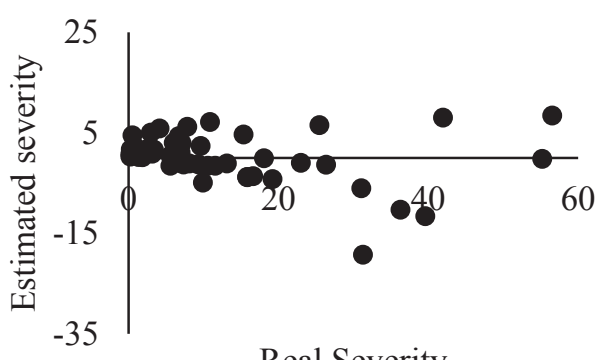

Real Severity

Evaluator 4

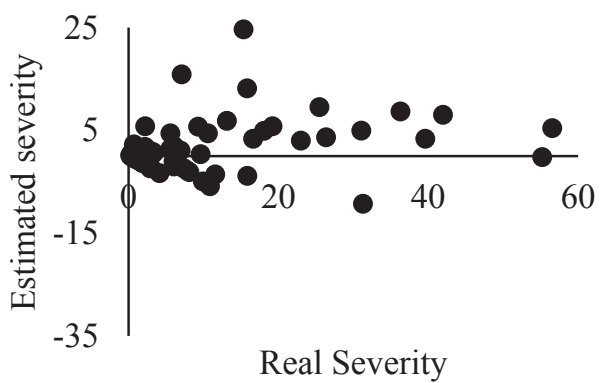

Evaluator 5

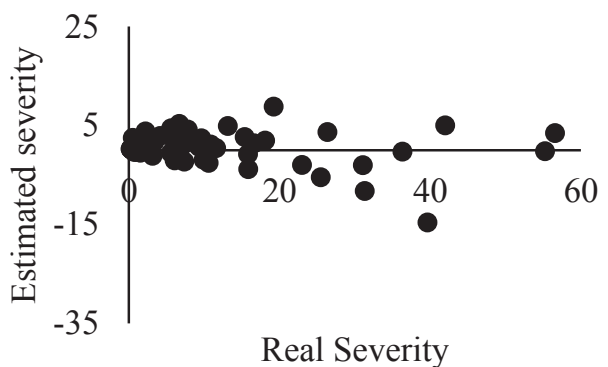

Evaluator 6

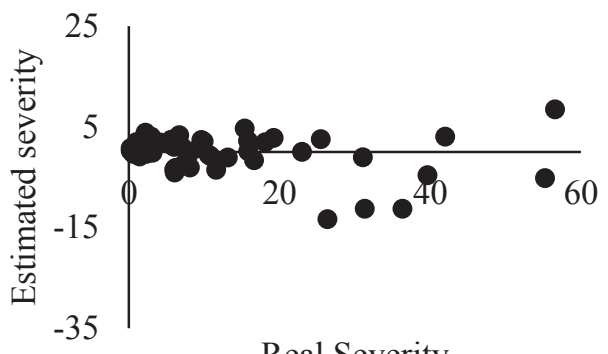

Real Severity

Evaluator 7

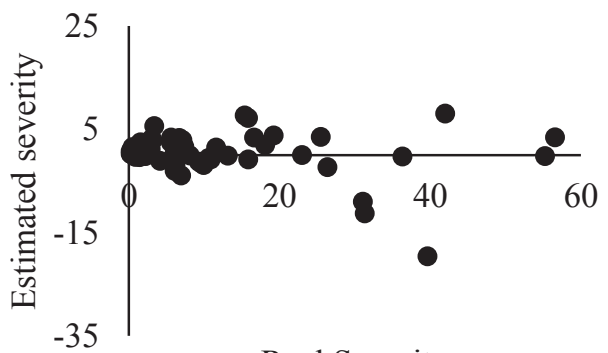

Real Severity

Evaluator 8

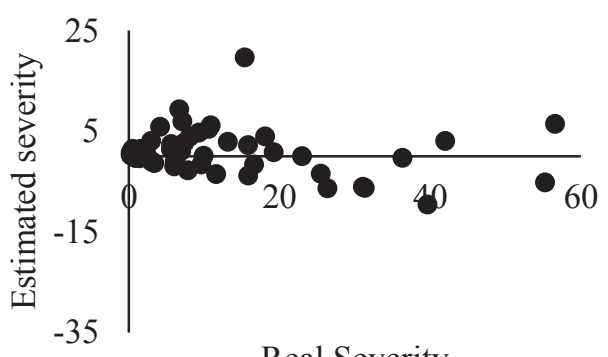




\section{Conclusion}

We developed and validated an effective diagrammatic scale to evaluate leaf spot severity caused by $D$. macrospora in maize. We show that assessments performed using the scale were fast and easy, facilitating accurate and precise estimates. Thus, we provide a useful tool for research related to this disease.

\section{References}

ALVES, G. C. S.; SANTOS, L. C.; DUARTE, H. S. S.; DIAS, V.; ZAMBOLIM, L.; ROCHA, M. R. Escala diagramática para quantificação da ferrugem da folha do trigo. Multi-Science Journal, Urataí, v. 1, n. 1, p. 128133, 2015. DOI: $10.33837 / \mathrm{msj} . v 1 \mathrm{il} .59$

AMORIM, L.; BERGAMIN FILHO, A. Fenologia, patometria e quantificação de danos. In: AMORIN, L.; REZENDE, J. A. M.; BERGAMIN FILHO, A. Manual de fitopatologia: princípios de conceitos. 5. ed. Ouro Fino: Ceres, 2018. p. 499-518.

BAMPI, D.; CASA, R. T.; BOGO, A.; SANGOI, L.; SACHS, C.; BOLZAN, J. M.; PILETTI, G. Desempenho de fungicidas no controle da mancha-de-macrospora na cultura do milho. Summa Phytopathologica, Botucatu, v. 38 , n. 4 , p. $319-322,2012$. DOI: $10.1590 / \mathrm{S} 0100-$ 54052012000400008

BERGAMIN FILHO, A.; AMORIM, L. Princípios gerais de controle. In: AMORIN, L.; REZENDE, J. A. M.; BERGAMIN FILHO, A. Manual de fitopatologia: princípios de conceitos. 5. ed. Ouro Fino: Ceres, 2018. v. 1, p. $215-228$.

BRUNELLI, K. R.; SOBRINHO, C.A.; CAVALCANTI, L. S.; FERREIRA, P. T. O.; CAMARGO, L. E. A. Germinação e penetração de Stenocarpella macrospora em folhas de milho. Fitopatologia Brasileira, Brasília, v. 30 , n. 2 , p. $187-190,2005$. DOI: $10.1590 / \mathrm{S} 0100-$ 54052012000400008

CAPUCHO, A. S.; ZAMBOLIM, L.; DUARTE, H. S. S.; VAZ, G. R. O. Develop-e ment and validation of a standard area diagram set to estimate severity of leaf rust in Coffea arabica and C. canephora. Plant Pathology, London, v. 60, n. 6, p. 1144-1150, 2011. DOI: 10.1111/j.1365-3059.2011.02472.x

CARVALHO, R. V.; PEREIRA, O. A. P.; CAMARGO, L. E. A. Doenças do milho. In: AMORIM, L.; REZENDE, J. A. M; BERGAMIN FILHO, A.; CAMARGO, L. E. A. Manual de fitopatologia: doenças das plantas cultivadas.
5. ed. Ouro Fino: Ceres, 2016. v. 2, p. 549-560.

COMPANHIA NACIONAL DE ABASTECIMENTO. ACOMPANHAMENTO DA SAFRA BRASILEIRA - CONAB. Grãos. Monitoramento agrícola - Safra 2017/18, v. 5, n. 4, 2018. (Quarto Levantamento).

CUSTÓDIO, A. A. P.; POZZA, E. A.; GUIMARÃES, S. S. G.; KOSHIKUMO, É. S. M.; HOYOS, J. M. A.; SOUZA, P.E. Comparison and validation of diagrammatic scales for brown eye spots in coffee tree leaves. Ciência e Agrotecnologia, Lavras, v. 35, n. 6, p. 1067-1076, 2011. DOI: $10.1590 / \mathrm{S} 1413-70542011000600005$

DOMICIANO, G. P.; DUARTE, H. S. S.; MOREIRA, E. N.; RODRIGUES, F. A. Development and a validation of a set of standard area diagrams to aid in estimation of spot blotch severity on wheat leaves. Plant Pathology, London, v. 63, n. 4, p. 922-928, 2013. DOI: 10.1111/ ppa. 12150

DUARTE, H. S. S.; ZAMBOLIM, L.; CAPUCHO, A. S.; NOGUEIRA JUNIOR, A. F.; ROSARDO, A. W. C.; CARDOSO, C. R.; PAUL, P. A.; MIZUBUTI, S. G. Development and validation of a set of standard area diagrams to estimate severity of potato early blight. European Journal Plant Pathology, Dordrecht, v. 137, p. 249-257, 2013. DOI: 10.1111/ppa.12150

EDDINS, A. H. Dry rot of corn caused by Diplodia macrospora Earle. Phytopathology, Sant Paul, v. 20, n. 3, p. 439-448, 1930.

FAO. Food and Agriculture Organization. Production: crops. 2017. Disponível em: http://www.fao.org/ faostat/ en/\#home. Acesso em: 29 dez. 2017.

JULIATTI, F. C.; CRATO, F. F.; JULIATTI, F. C.; COUTO, K. R.; JULIATTI, B. C. M. Escala diagramática para avaliação da severidade de mofo branco em soja. Bioscience Journal, Uberlandia, v. 29, n. 3, p. 676-680, 2013.

LATTERELL, F. M.; ROSSI, A. E. Stenocarpella macrospora (=Diplodia macrospora) and $S$. maydis $(=D$. maydis) compared as pathogens of corn. Plant Disease, Sant Paul, v. 67, n. 7, p. 725-729, 1983.

LENZ，G.; BALARDIN， R. S.; CORTE， G. D.; MARQUES, L. N.; DEBONA, D. Escala diagramática para avaliação de severidade de mancha-parda em arroz. Ciência Rural, Santa Maria, v. 40, n. 4, p. 752-758, 2010. DOI: $10.1590 / \mathrm{S} 0103-84782010005000061$

LIMA, H. E.; NECHET, K. L. VIEIRA, B. A. H. OLIVEIRA, J. R.; DUARTE, H. S. S.; QUEIROZ, E. S.; OLIVEIRA, F. L. Elaboração e validação de escalas diagramáticas para avaliação da severidade da manchabacteriana do feijão - caupi em cultivares com trifólios 
morfologicamente distintos. Ciência Rural, Santa Maria, v. 43 , n. 10 , p. $1735-1743$, 2013. DOI: 10.1590/S010384782013001000001

NUNES, C. C.; ALVES, S. A. M. Elaboração e validação de escala diagramática para quantificação da severidade de entomosporiose em folhas de pereira. Summa Phytopathologica, Botucatu, v. 38, n. 3, p. 239-244, 2012. DOI: $10.1590 / \mathrm{S} 0100-54052012000300011$.

NUTTER JUNIOR, F. W.; SCHULTZ, P. M. Improving the accuracy and precision of disease assessments: selection of methods and use of computer-aided training programs. Canadian Journal of Plant Pathology, Ottawa, v. 17, p. 174-184, 1995. DOI: 10.1080/07060669509500709.

OLIVEIRA, P.; NASCENTE, A. S.; KLUTHCOUSKI, J.; PORTES, T. A. Crescimento e produtividade de milho em função da cultura antecessora. Pesquisa Agropecuária Tropical, v. 43 n. 3, p. 239-246, 2013. DOI: 10.1590/ S1983-40632013000300005

REIS, E. M.; CASA, R. T.; BRESOLIN, A. C. R. Development and validation of a standard area diagram set to assess blast severity on wheat leaves. European Journal Plant Pathology, Dordrecht, v. 136, p. 603-611, 2013. DOI: $10.1007 / \mathrm{s} 10658-013-0191-\mathrm{x}$

SIQUEIRA, C. S.; MACHADO, J. C.; BARROCAS, E. N.; ALMEIDA, M. F. Potential for transmission of
Stenocarpella macrospora from inoculated seeds to maize plants grown under controlled conditions. Journal of Seed Science, Londrina, v. 36, n. 2, p. 154-161, 2014. DOI: $10.1590 / 2317-1545 v 40 n 1181833$

SOUSA, S. C. R.; SANTOS, G. R.; RODRIGUES, A. C.; BONIFÁCIO, A.; DALCIN, M. S.; JULIATTI, F. C. Escala diagramática para avaliação da severidade do crestamento gomoso do caule em melancia. Bioscience Journal, v. 30, n. 5, p. 1314-1324, 2014.

TERAMOTO, A.; AGUIAR, R.A.; GARCIA, R.A.; MARTINS, M.C.; CUNHA, M.G. Escala diagramática para avaliação da severidade da mancha alvo em folhas de pepineiro. Pesquisa Agropecuária Tropical, Goiânia, v. 41, n. 3, p. 439-445, 2011. DOI: 10.5216/pat. v41i3.12017

TROJAN, D. G.; PRIA, M. D. Validação de escala diagramática para quantificação da severidade da antracnose da folha do milho. Summa Phytopathologica, Botucatu, v. 44, n. 1, p. 56-64, 2018. DOI: 10.1590/0100$5405 / 172675$

VALE, F. X. R; FERNANDES FILHO, E. I. F.; LIBERATO, J. R. QUANT: a software to quantify plant disease severity. In: INTERNATIONAL WORKSHOP ON PLANT DISEASE EPIDEMIOLOGY, 8, Ouro Preto, 2001. Proceeding... Ouro Preto: The International Society of Plant Pathology, 2001. p. 1-160. 